\title{
FAKTOR RISIKO KOMPONEN FISIK RUMAH TERHADAP KEJADIAN PNEUMONIA DI DESA TRAJI KECAMATAN PARAKAN KABUPATEN TEMANGGUNG TAHUN 2015
}

\author{
Dian Wahyu Aprilyani' ${ }^{1}$, Budi Utomo ${ }^{2)}$ \\ Jurusan Kesehatan Lingkungan, Politeknik Kesehatan Kemenkes Semarang, \\ Jl. Raya Baturaden KM 12 Purwokerto, Indonesia
}

\begin{abstract}
Abstrak
Pneumoniadi kalangan masyarakat umumnya disebabkan oleh bakteri, virus, mikoplasma dan protozoa. Lingkungan khususnya perumahan sangat berpengaruh pada peningkatan resiko terjadinya pneumonia seperti suhu, kelembaban, intensitas cahaya, ventilasi, jenis dinding, jenis lantai, kepadatan hunian bahkan perilaku penghuni rumah. Penelitian ini bertujuan untuk mengetahui faktor risiko komponen fisik rumah terhadap kejadian pneumonia di Desa Traji Kecamatan Parakan Kabupaten Temanggung. Jenis penelitian ini adalah Observasional dengan pendekatan Case Control dan analisis data dengan uji Chi-square. Hasil penelitian ini adalah faktor risiko komponen fisik rumah berdasarkan analisis bivariat berupa jenis lantai rumah dengan nilai OR= 8,222 $(95 \%$ $C I=1,87-36,049)$. Sedangkan yang bukan faktor risiko komponen fisik rumah meliputi suhu memenuhi syarat semua, kelembaban $O R=0,888(95 \% C I=0,01-0,72)$, intensitas cahaya $O R=0,6(95 \% C I=0,127-3,13)$, ventilasi $O R=0,333(95 \% C I=0,08-1,2)$, jenis dinding $O R=1,222(95 \% C I=0,41-3,58)$ dan kepadatan hunian rumah $O R=0,77(95 \% C I=0,23-2,56)$. Kesimpulan penelitian ini adalah faktor komponen fisik rumah yang menjadi risiko kejadian pneumonia yaitu jenis lantai. Dan faktor komponen fisik rumah yang bukan menjadi risiko kejadian pneumonia yaitu suhu, kelembaban, intensitas cahaya, ventilasi, jenis dinding dan kepadatan hunian rumah.Peneliti lain dapat melakukan penelitian selanjutnya yang lebih dalam dengan sampel lebih besar.
\end{abstract}

Kata kunci : Faktor Risiko Komponen Fisik Rumah

\begin{abstract}
The pneumonia incidence the society generally is caused by bacteria, viruses, mycoplasma and protozoa. The housing environment particularlywas very influential in the increased risk of pneumonia such as temperature, humidity, light intensity, ventilation, walls type, floor type, residential density and resident's behavior. The research objective was identifying the pneumonia incidence housing physical components risk factors in Traji sub-district Parakan District Temanggung Regency. The research design used was observational with Case Control approach and the data analysis used was Chi-square test. The analysis result shows that the housing physical components risk factors based on bivariate analysis was floor types with OR $=8.222(95 \%$ CI $=1.87$ to 36.049). Whereas non risk factor for physical components was temperature, all the housing qualify the requirements, moisture OR $=0.888$ $(95 \% C I=.01-.72)$, light intensity $O R=0.6(95 \% C I=0.127$ to 3.13$)$, ventilation $O R=0.333(95 \% C I=0.08$ to 1.2), wall type $O R=1.222(95 \% C I=0.41$ to 3.58$)$ and the residential density $O R=0.77(95 \% C I=0.23$ to 2.56$)$. The conclusion drawn was; the housing physical component factors that became pneumonia risk was floor type. Whereas non risk factor for physical components was temperature, humidity, light intensity, ventilation, wall type and residential density. Other researchers can conduct further in depth research using larger samples.
\end{abstract}

Keywords : The housing physical component factors

\section{PENDAHULUAN}

World Health Organization (WHO) memperkirakan kejadian pneumonia di Negara dengan angka kematian bayi diatas 40 per 1.000 kelahiran hidup adalah $15 \%-20 \%$ pertahun pada golongan usia balita.

Pneumonia merupakan penyakit yang paling banyak menyebabkan kematian khususnya pada balita diantara penyakit ISPA lainnya yaitu sekitar 80-90\% (Kemenkes RI, 2013).
Penurunan penemuan kasus pneumonia ini disebabkan oleh kurangnya dukungan pemerintah daerah dalam upaya mengendalikan penyakit pneumonia seperti kekuranglengkapan pelaporan data penemuan kasus pneumonia balita di kota / kabupaten (Depkes RI, 2010). Akibat rendahnya kepatuhan petugas kesehatan dalam menjalankan Standar Opersional Prosedur yang belum maksimal sehingga banyak kasus pneumonia balita tidak terdeteksi, disamping itu belum maksimalnya 
sosialisasi kepada masyarakat tentang tanda-tanda pneumonia pada balita serta bahayanya bila tidak segara ditangani sangat berpengaruh terhadap rendahnya cakupan penemuan kasus pneumonia balita (Dinkes Jateng, 2008).

Faktor risiko yang meningkatkan kematian (mortalitas) akibat pneumonia merupakan gabungan faktor risiko insiden ditambah dengan faktor tatalaksana dipelayanan kesehatan yang meliputi ketersediaan pedoman tatalaksana, ketersediaan tenaga kesehatan terlatih yang memadai, kepatuhan tenaga kesehatan terhadap pedoman, ketersediaan fasilitas yang diperlukan untuk tatalaksana pneumonia (obat, oksigen, perawatan intensif), prasarana dan sistem rujukan (Depkes RI, 2009).

Kondisi rumah dan lingkungan dapat mempengaruhi kejadian penyakit pneumonia. Konstruksi rumah dan lingkungan yang tidak memenuhi syarat kesehatan merupakan faktor risiko penularan berbagai jenis penyakit berbasis lingkungan, salah satunya pneumonia (Dinkes Jateng, 2009).

Rumah sehat merupakan salah satu sarana untuk mencapai derajat kesehatan yang optimum. Rumah juga merupakan salah satu bangunan tempat tinggal yang harus memenuhi kriteria kenyamanan, keamanan dan kesehatan guna mendukung penghuninya agar dapat bekerja dengan produktif (Arifin, 2009).

Cakupan rumah sehat tahun 2008 di Jawa Tengah baru mencapai 58,83\% dan belum mencapai target Standar Pelayanan Minimal (SPM) sebesar 65\% (Dinas Kesehatan Jateng, 2009).

Data 3 tahun terakhir cakupan rumah sehat memenuhi syarat di Desa Traji Kecamatan Parakan mengalami kenaikan dari tahun 2012 69,5\% tahun 2013 72\%. Di tahun 2014 data rumah sehat yang memenuhi syarat mengalami kenaikan $10 \%$ dari sebelumnya. Hal ini menunjukkan bahwa upaya penyehatan yang di lakukan oleh pihak sanitarian puskesmas Traji sebelumnya telah dilaksanakan dengan baik (Puskesmas Traji, 2014).

Berdasarkan permasalahan diatas maka penulis mencoba mengadakan penelitian dengan judul "Faktor Risiko Komponen Fisik Rumah Terhadap Kejadian Pneumonia Di Desa Traji Kecamatan Parakan Kabupaten Temanggung tahun 2015"

\section{BAHAN DAN METODE}

Penelitian ini menggunakan jenis penelitian Observasional dengan pendekatan Case Control. Penelitian ini menggunakan jenis penelitian Observasional dengan pendekatan Case Control. Penelitian ini merupakan rancangan penelitian yang membandingkan antara kelompok kasus dengan kelompok kontrol untuk mengetahui proporsi kejadian berdasarkan riwayat ada tidaknya paparan.

Populasi penelitian ini terbagi menjadi 2 kelompok yaitukelompok kasus balita pneumonia di Desa Traji pada tahun 2014 yaitu 40 balita dan kelompok kontrol semua balita yang tidak pneumonia di Dusun Gandu Desa Gandu Wetan Kecamatan Ngadirejo Kabupaten Temanggung pada tahun 2014 yaitu 44 balita. Sampel penelitian ini terbagi menjadi 2 kelompok yaitu kelompok kasus dalam penelitian ini adalah jumlah 50\% dari seluruh balita yang pneumonia yaitu 20 kasus di ambil kasus terakhir tahun 2014 di Desa Traji Kecamatan Parakan Kabupaten Temanggung dan kelompok kontrol Kontrol dalam penelitian ini adalah dari jumlah sampel yang diambil 2 kali jumlah kasus yaitu 40 kasus balita yang tidak pneumonia diambil di Dusun Gandu Desa Gandu Wetan Kecamatan Ngadirejo Kabupaten Temanggung dengan jenis kelamin yang sama dan umur mendekati kasus.

Analisis yang digunakan pada penelitian ini analisis univariat dan analisis bivariat dengan uji $C h i$ square.

\section{III.HASIL DAN PEMBAHASAN}

Hasil penelitian suhu rumah responden menggunakan alat berupa termometer ruang rata-rata antara $28{ }^{\circ} \mathrm{C}$. Suhu rumah responden memenuhi syarat kesehatan perumahanyaitu $18^{\circ} \mathrm{C}-30^{\circ} \mathrm{C}$. Bakteri Streptococcus pneumoniae tumbuh aerob dan anaerob fakultatif pada suhu $30^{\circ} \mathrm{C}-35^{\circ} \mathrm{C}$, sehingga bakteri ini tidak dapat tumbuh subur di Desa Traji dan bakteri tersebut sulit untuk tumbuh pada suhu dibawah $25^{\circ} \mathrm{C}$ dan diatas $41^{\circ} \mathrm{C}$.

Hasil kelembaban rumah responden yang tidak memenuhi syarat pada kasus dan kontrol sebanyak 16 dari 60 (26,7\%), sedangkan kelembaban rumah responden yang memenuhi syarat sebanyak 44 dari $60(73,3 \%)$. Berdasarkan hasil chi-square didapatkan bahwa nilai $\mathrm{p}=0,018$ yang artinya Ho ditolak, sehingga dapat disimpulkan bahwa ada hubungan antara kelembaban rumah terhadap kejadian pneumonia di Desa Traji. Hasil nilai OR sebesar 0,8 $(95 \%$ CI $=0,01-0,72)$ yang berarti bahwa kelembaban rumah bukan faktor risiko kejadian pneumonia.Dalam penelitian ini kelembaban rumah sebagai variabel pendukung karena dapat dipengaruhi oleh beberapa hal seperti lingkungan rumah yang tidak memenuhi syarat atau oleh cuaca. Kelembaban rumah yang memenuhi syarat yaitu 40\%-60\%.

Hasil intensitas cahaya rumah responden yang tidak memenuhi syarat pada kasus dan kontrol sebanyak 53 dari $60(88,3 \%)$, sedangkan intensitas cahaya rumah responden yang memenuhi syarat 7 dari $60(11,7 \%)$. Pada uji chi-square didapatkan nilai $\mathrm{p}=0.676$ yang artinya Ho diterima, sehingga dapat disimpulkan bahwa tidak ada hubungan intensitas cahaya rumah terhadap kejadian pneumonia di Desa Traji. Hasil nilai OR sebesar 0,6 (95\% CI = 0,127 3,132 ) yang berarti bahwa intensitas cahaya rumah bukan faktor risiko kejadian pneumonia.Intensitas cahaya rumah merupakan variabel pendukung, hal ini di pengaruhi karena Intensitas cahaya yang masuk ke medium tertentu maka sebagian gelombang dipantulkan oleh permukaan, sisanya akan menembus 
medium dan sebagian yang menembus tersebut akan diserap dan sebagian lagi diteruskan sebagaimana hukum termodinamika 1 (Aris Santjaka, 2013).

Hasil ventilasi rumah responden yang tidak memenuhi syarat pada kasus dan kontrol sebanyak 49 dari 60 (81,7\%), sedangkan ventilasi rumah responden yang memenuhi syarat sebanyak 11 dari $60(18,3 \%)$. Pada uji chi-square didapatkan nilai $\mathrm{p}=$ 0.155 yang artinya Ho diterima, sehingga dapat disimpulkan bahwa tidak ada hubungan antara ventilasi rumah responden terhadap kejadian pneumonia di Desa Traji. Hasil nilai OR sebesar $0,333(95 \% \mathrm{CI}=0,08-1,2)$ yang berarti bahwa ventilasi rumah bukan faktor risiko kejadian pneumonia.

Ventilasi yang baik dapat membebaskan udara ruangan dari bakteri patogen karena dengan adanya ventilasi, udara bertukar secara terus menerus. Ventilasi rumah yang tidak memenuhi syarat dapat dijadikan indikator bahwa kurangnya pemahaman mengenai rumah sehat dengan ventilasi yang sesuai ketentuan yakni minimal $10 \%$ dari luas rumah.

Hasil jenis dinding rumah responden yang tidak memenuhi syarat pada kasus dan kontrol sebanyak 31 dari $60(51,7 \%)$, sedangkan jenis dinding responden yang memenuhi syarat sebanyak 29 dari 60 (48,3\%). Hasil chi-square nilai $\mathrm{p}=0,927$ yang artinya Ho diterima, sehingga dapat disimpulkan bahwa tidak ada hubungan antara jenis dinding rumah responden terhadap kejadian pneumonia di Desa Traji. Hasil nilai OR sebesar 1,222 (95\% CI $=0,41-3,58)$ yang berarti bahwa jenis dinding rumah bukan faktor risiko kejadian pneumonia. Dimana nilai OR $>1$ tetapi batas bawah $\mathrm{CI}<1$ sehingga bukan sebagai faktor risiko.Dinding berfungsi sebagai pelindung rumah yang terbuat dari berbagai bahan seperti bambu, triplek, batu bata dan dari bahan tersebut yang paling baik yaitu yang terbuat dari batu bata atau tembok.

Hasil observasi jenis lantai rumah responden sebagian besar tanah, ubin dan kramik. Jenis lantai yang tidak memenuhi syarat pada kasus dan kontrol sebanyak 11 dari 60 (18,3\%), sedangkan jenis lantai rumah responden yang memenuhi syarat sebanyak 49 dari $60(81,7 \%)$. Berdasarkan hasil chi-square didapatkan bahwa nila $\mathrm{p}=0.004$ yang artinya Ho ditolak, sehingga dapat disimpulkan bahwa ada hubungan antara jenis lantai rumah responden terhadap kejadian pneumonia di Desa Traji. Hasil nilai OR sebesar 8,222 (95\% CI = 1,875 - 36,049) yang berarti bahwa jenis lantai rumah sebagai faktor risiko kejadian pneumonia.Persayaratan rumah sehat memeiliki lantai yang terbuat dari marmer, ubin, kramik dan sudah diplester semen.

Hasil kepadatan hunian rumah yang tidak memenuhi syarat pada kasus dan kontrol sebanyak 44 dari 60 (73,3\%), sedangkan kepadatan hunian rumah yang memenuhi syarat sebanyak 16 dari 60 (26,7\%). Hasil uji chi-square nilai $\mathrm{p}=0,918$ yang artinya Ho diterima, sehingga dapat disimpulkan bahwa tidak ada hubungan antara kepadatan hunian rumah terhadap kejadian pneumonia di Desa Traji. Hasil nilai OR sebesar $0,77(95 \% \mathrm{CI}=0,23-2,56)$ yang berarti bahwa kepadatan hunian rumah yang bukan faktor risiko kejadian pneumonia.Persyaratan kepadatan hunian untuk rumah sehat dikatakan padat/ tidak memenuhi syarat apabila luas rumah dibagi penghuni adalah $<10 \mathrm{~m}^{2}$.

\section{IV.KESIMPULAN}

Suhu rumah dari 60 responden di Desa Traji memenuhi syarat.Kelembaban rumah responden yang tidak memenuhi syarat sebesar 16 dari 60 (26,7\%) dan kelembaban rumah responden yang memenuhi syarat 44 dari $60(73,3 \%)$. Intensitas cahaya rumah responden yang tidak memenuhi syarat sebesar 53 dari 60 (88,3\%) dan intensitas cahaya rumah responden yang memenuhi syarat sebesar 7 dari 60 $(11,7 \%)$.Ventilasi rumah responden yang memenuhi syarat sebesar 49 dari $60(81,7 \%)$ dan ventilasi rumah responden yang memenuhi syarat sebesar 11 dari 60 $(18,3 \%) . J e n i s$ dinding rumah responden yang tidak memenuhi syarat sebesar 31 dari $60(51,7 \%)$ dan jenis dinding rumah responden yang memenuhi syarat sebesar 29 dari 60 (48,3\%).Jenis lantai rumah responden yang tidak memenuhi syarat sebesar 11 dari $60(18,3 \%)$ dan jenis lantai rumah responden yang memenuhi syarat sebesar 49 dari $60(81,7 \%)$. Kepadatan hunian rumah responden yang tidak memenuhi syarat sebesar 44 dari $60(73,3 \%)$ dan kepadatan hunian rumah responden yang memenuhi syarat sebesar 16 dari 60 (26,7\%).Faktor komponen fisik rumah yang menjadi faktor risiko kejadian pneumonia adalah jenis lantai rumah.Faktor-faktor komponen fisik rumah yang tidak menjadi faktor risiko kejadian pneumonia adalah suhu, kelembaban, intensitas cahaya, ventilasi, jenis dinding dan kepadatan hunian rumah.

\section{DAFTAR PUSTAKA}

$\begin{gathered}\text { Anonim,9 } \\ \text { September }\end{gathered}$
$\frac{\text { http://ispa.pppl.depkes.go.id/unduh/PEDOMA }}{2014}$
12.03 WIB

Anonim

http://lontar.ui.ac.id/file?file=digital/20313307 -T\%2031721-Hubungan\%20antara-

full\%20etxt.pdf 11 September 2014 pukul 11.31 WIB

Anonim,

http://datatopics.worldbank.org/hnp/files/edsta ts/IDNbr10b.pdf

10 November 2014 pukul 11.38 WIB

Anonim,

http://digilib.ump.ac.id/files/disk1/20/jhptump

-ump-gdl-suryofebri-969-2-babii.pdf 
Anonim,

http://www.ejournal.undip.ac.id/index.php/jkli /article/viewFile/5031/4562

10 September 2014 pukul 14.31 WIB

Cahyono, Tri. (2014). Pedoman Penulisa Proposan dan Karya Tulis Ilmiah / Skripsi (Edisi revisi ketiga). Purwokerto: Poltekkes Kemenkes Semarang Jurusan Kesehatan Lingkungan Purwokerto

Chin, James. (2006). Pemberantasan Penyakit Menular (Edisi 17). Jakarta: Infomedika

Dinas Kesehatan Kabupaten Temanggung. (2014). Data Pneumonia. Kabupaten Temanggung

Ema Setianingrum, (2013). Hubungan Faktor Lingkungan Fisik Rumah Dengan Kejadian ISPA Pada Balita Di Desa Kalitinggar Kecamatan Padamara Kabupaten Purbalingga Tahu 2013. Purwokerto: Politeknik Kesehatan Kemenkes Semarang Jurusan Kesehatan Lingkungan Purwoerto.

Jawetz, Ernest, Josep Melnick dan Edward Adelberg. (1996). Mikrobiologi Kedokteran. Jakarta: EGC

Keputusan Menteri Kesehatan Republik Indonesia Nomor : 1077 / MENKES / PER / V / (2011). Tentang Pedoman Penyehatan Udara Dalam Ruang Rumah.

Notoatmodjo, Soekidjo. (2010). Metode Penelitian Kesehatan. Jakarta: Rineka Cipta
Price, Sylvia dan Wilson, Lorraine. (2005). Patofisiologi Konsep Klinis Proses-Proses Penyakit. Jakarta: EGC

Rahmayatul Fillacano, (2013). Hubungan Lingkungan Dalam Rumah Terhadap ISPA Pada Balita Di Kelurahan Ciputat Kota Tangerang Selatan Tahun 2013. Jakarta: Fakultas Kedokteran dan Ilmu Kesehatan Universitas Islam Negeri Syarif HidayatullahJakarta http://repository.uinjkt.ac.id/dspace/bitstream/ 123456789/24284/1/RAHMAYATUL\%20FIL LACANO-fkik.pdf 11 September 2014 pukul 12.40 WIB

Ramlan, Djamaluddin dan Maisye Marlyn Kuhu. (2014). Penulisan Penelitian Eksplanatif. Purwokerto: UPT. Percetakan dan Penerbitan UNSOED Grendeng

Santjaka, Aris. (2013). Malaria Pendekatan Metode Kausalitas. Yogyakarta. Nuha Medika

Santjaka, Aris. (2011). Statistika Untuk Penelitian kesehatan. Yogyakarta: Nuha Medika

Tanti Isna Annisatulhusna. (2010). Hubungan Tingkat Ekonomi Sosial Dengan Kejadian Pneumonia Pada Balita Di Puskesmas I Sokaraja Kabupaten Banyumas Tahun 2010. Purwokerto: Politeknik Kesehatan Kemenkes Semarang Jurusan Kesehatan Lingkungan Purwoerto

Undang-undang RI No. 1 Tahun (2011) Tentang Perumahan dan Kawasan Permukiman 